\title{
Universal Design for Learning in Assessment: Supporting ELLs with Learning Disabilities
}

Diseño universal para el aprendizaje en la evaluación: apoyo a los ELL con dificultades de aprendizaje

Design universal para a aprendizagem na avaliação: apoio aos ELLs com dificuldades de aprendizagem

Thomas A. DELANEY

https://orcid.org/0000-0002-2778-0540

University of Oregon, United States of America

Maiko HATA

https://orcid.org/0000-0002-2688-5957

Willamette Education Service District, United States of America maiko.hata@wesd.org

Received: 16/10/2019

Accepted by peers: 07/02/2020

DOI: 10.5294/laclil.2020.13.1.5
Sent to peer review: 07/01/2020

Approved: 25/02/2020

To reference this article (APA) / Para citar este artículo (APA) / Para citar este artigo (APA) Delaney, T. A., \& Hata, M. (2020). Universal design for learning in assessment: Supporting ELLs with learning disabilities. Latin American Journal of Content \& Language Integrated Learning, 13(1), 79-91. https://doi.org/10.5294/laclil.2020.13.1.5 
ABSTRACT. Studying English is challenging and, for many learners, undiagnosed learning disabilities can present a serious threat to their success. Recent studies indicate that up to $10 \%$ of the world population has a non-apparent disability, such as autism or dyslexia. At the same time, few English language learner (ELL) instructors in higher education have training in learning disabilities, and they are often unsure of how to support learners who seem to have extra challenges. This is especially true when it comes to assessment, as instructors often rely on traditional tools that could negatively affect the validity of the assessment outcomes. In this brief reflection, the authors share how instructors can apply the principles of Universal Design for Learning (UDL) to their assessment practices to support students with disabilities, regardless of diagnostic status. First, disabilities that affect language learning will be briefly discussed, followed by the explanation of how English to speakers of other languages (ESOL) assessments present specific challenges for students with disabilities. Then, the authors will provide an overview of UDL theory, which proposes that learners with disabilities are often best served by accommodations in representation, expression and engagement that can benefit the entire class. Most of the paper will focus on specific, practical strategies for implementing UDL within assessment in higher education. Such strategies include building executive function, implementing multi-channel assessment, and learning about students through an "evaluation loop."

Keywords (Source: Unesco Thesaurus): learning disabilities; universal design; universal design for learning; UDL; assessment; evaluation; higher education.

RESUMEN. Estudiar inglés es un desafío y, para muchos estudiantes, las discapacidades de aprendizaje no diagnosticadas pueden representar una seria amenaza para su éxito. Los más recientes estudios indican que, hasta un 10 \% de la población mundial tiene una discapacidad no aparente, como el autismo o la dislexia. Al mismo tiempo, pocos profesores de aprendices de inglés (ELL) en educación superior han recibido entrenamiento en discapacidades de aprendizaje y, a menudo, no están seguros de cómo apoyar a los alumnos que parecen tener otros desafíos. Esto es particularmente cierto en lo que respecta a la evaluación, ya que los instructores a menudo se basan en herramientas tradicionales que podrían afectar negativamente la validez de los resultados de la evaluación. En esta breve reflexión, los autores comparten cómo los instructores pueden aplicar los principios del Diseño Universal para el Aprendizaje (DUA) a sus prácticas de evaluación para apoyar a los estudiantes con discapacidades, independientemente del estado de diagnóstico. Luego, los autores proporcionarán una descripción general de la teoría DUA, que propone que los estudiantes con discapacidades a menudo se benefician más con adaptaciones en representación, expresión y participación que pueden beneficiar a toda la clase. La mayor parte del artículo se centrará en estrategias prácticas específicas para implementar la DUA dentro de la evaluación en la educación superior. Dichas estrategias incluyen desarrollar la función ejecutiva, implementar evaluaciones multicanal y aprender sobre los estudiantes a través de un "ciclo de evaluación".

Palabras clave (Fuente: tesauro de la Unesco): dificultad en el aprendizaje; diseño universal; diseño universal para el aprendizaje; diseño universal para el aprendizaje; DUA; valoración; evaluación; enseñanza superior.

RESUMO. Estudar inglês é um desafio e, para muitos alunos, deficiências de aprendizado não diagnosticadas podem representar uma séria ameaça ao seu sucesso. Os estudos mais recentes indicam que até $10 \%$ da população mundial tem uma deficiência não aparente, como autismo ou dislexia. Ao mesmo tempo, poucos professores de alunos aprendizes de inglês (ELL) no ensino superior receberam treinamento em dificuldades de aprendizagem e muitas vezes não têm certeza de como apoiar os alunos que parecem ter desafios adicionais. Isso é particularmente certo quando se trata de avaliação, já que os instrutores geralmente têm ferramentas tradicionais que podem afetar negativamente a validade dos resultados da avaliação. Nesta breve reflexão, os autores compartilham como os instrutores podem aplicar os princípios do Design Universal para Aprendizagem (DUA) em suas práticas de avaliação para apoiar os alunos com deficiência, independentemente do status do diagnóstico. Os autores fornecerão uma visão geral da teoria DUA, que propõe que os alunos com deficiência muitas vezes se beneficiam mais de adaptações na representação, expressão e participação que podem beneficiar toda a classe. A maior parte do artigo se concentrará em estratégias práticas específicas para implementar o DUA na avaliação do ensino superior. Essas estratégias incluem o desenvolvimento da função executiva, a implementação de avaliações multicanais e o aprendizado dos alunos por meio de um "ciclo de avaliação".

Palavras-chave (Fonte: tesauro da Unesco): dificuldade no aprendizado; desenho universal; desenho universal para o aprendizado; desenho universal para o aprendizado; DUA; avaliação; avaliação; ensino superior. 


\section{Introduction}

In recent years, higher-education institutions all over the world have witnessed a dramatic increase in the number of students who report having disabilities. For example, approximately 19\% of all undergraduates in U.S. colleges and universities report having a disability (Snyder et al., 2019). While such numbers may be lower in other countries, many are making progress in recognizing disabilities as well. For example, the number of undergraduate students who report having disabilities in Japan climbed from 4,937 in 2006 to 14,127 in 2014, as well. This is partially a result of the exponential increase in the number of students diagnosed with developmental disabilities, including learning disabilities, autism, and mental illnesses. The number of students diagnosed with these conditions went from 506 in 2006 to 5,866 in 2014 (Japan Student Services Organization, 2015).

However, instructors of ELLs are often unequipped with strategies to work effectively with students with disabilities. In this brief paper, we will review what constitutes learning disabilities, introduce Universal Design for Learning (UDL) principles, and present some UDL-inspired practical applications in the area of assessment.

\section{Learning disabilities}

The Individuals with Disabilities Education Act, a key special education law in the U.S., defines a specific learning disorder as

a disorder in one or more of the basic psychological processes involved in understanding or in using language, spoken or written, which disorder may manifest itself in the imperfect ability to listen, think, speak, read, write, spell, or do mathematical calculations. Such term includes conditions such as perceptual disabilities, brain injury, minimal brain dysfunction, dyslexia, and developmental aphasia. (Individuals with Disabilities Education Act, 20 U.S.C. § 1400, 2004)

More inclusive working definitions often extend learning disabilities to include conditions such as attention deficit hyperactivity disorder (ADHD) and autism spectrum disorder (ASD). The American Psy- 
chiatric Association (2019a) defines ADHD as "one of the most common mental disorders affecting children" (para. 1) with symptoms such as "inattention (not being able to keep focus), hyperactivity (excess movement that is not fitting to the setting) and impulsivity (hasty acts that occur in the moment without thought)" (2019a, para. 1). Likewise, ASD is defined as "a complex developmental condition that involves persistent challenges in social interaction, speech and nonverbal communication, and restricted/repetitive behaviors. The effects of ASD and the severity of symptoms are different in each person" (American Psychiatric Association, 2019b, para 1).

Recent studies indicate that up to $10 \%$ of the world population has a non-apparent disability, including conditions such as autism or dyslexia (Butterworth \& Kovath, 2013). However, unlike physically apparent disabilities, these conditions are often underdiagnosed or not diagnosed at all. This is especially the case in countries where awareness of and resources for such disabilities are limited.

Yet, among the approximately $19 \%$ of undergraduates in the U.S. who report having a disability for which they receive official accommodations, the most commonly reported disabilities are ADHD (22\%), mental illnesses/depression (31\%) and specific learning disability or dyslexia (5\%). However, in many other countries, the resources to make accommodations for these learners are scarce (National Center for Education Statistics, 2011).

To make the matter even more complex, many who experience dyslexia also experience ADHD. Various studies suggest that an estimated one-third of those with learning disabilities also experience ADHD (Larson, 2011; NCLD, 2014).

In addition, the very nature of English can make it more challenging for ELLs with disabilities to learn the language. The International Dyslexia Association defines dyslexia as a neurological learning disability characterized by challenges with accurate and/or fluent word recognition (The International Dyslexia Association, 2019), not as a result of lack of instructions or intelligence. Although more research is necessary, many believe that the deep orthography of English can be a contributing factor to the added challenges that ELLs experience. That is, character-to-sound translation in English is not transparent (Nakayama \& Butterworth, 1999), unlike other languages such as Spanish, where almost one-to-one sound-letter correspondence can be observed. 
There is nothing to suggest that the rates of disability among ELLs in university English programs vary significantly from the general population numbers just cited, so this is certainly an issue of concern to English teachers with speakers of other languages.

\section{Assessment specific challenges and considerations}

Then, to tackle just one aspect of disability in higher education, how can we effectively support students with non-apparent disabilities, whether diagnosed or not diagnosed? Also, how might these conditions manifest in an ELL classroom? Many teachers may not be aware that approximately $10 \%$ of students in their classes have specific learning disabilities, ranging from mild to moderate autism, dyslexia, and/or ADHD. Clearly, our job as ELL educators is not to make diagnoses, but it is possible to identify and implement UDL approaches that can support many, if not all, the students in being assessed more fairly and with less anxiety. In order to do this, we first need to identify the challenges that classroom assessments can pose when evaluating learners' true potential. What are some of the difficulties students with the conditions mentioned above experience?

For those who find reading difficult:

- Reading and understanding test directions takes longer, costing them valuable time to answer questions.

- Reading texts takes more time and effort, causing premature fatigue.

For those who have difficulties keeping information in short-term memory:

- Remembering what they just read/heard to answer questions is challenging, which may require looking at directions repeatedly before answering actual questions.

- While such learners are still recalling what they just heard, the teacher might already be moving on to the next test item, leaving them with less time to process information and answer questions.

If processing information takes more time: 
- Understanding directions requires more time;

- Capacity to "hold" information is diminished;

- Complex and/or multi-part directions (e.g., "Put away the textbook, write your name on the top of the test, and don't flip the test paper yet.") are challenging.

If focusing is difficult:

- Learners might be easily distracted (e.g., noise outside, a classmate coughing, too much text to process).

- Learners may miss important directions as they come in and out of focus.

- Learners may find it extremely difficult to get motivated to study.

\section{Universal Design for Learning}

Universal Design for Learning (UDL) is a framework that serves to improve teaching and learning for everyone (CAST, 2019). UDL proposes that learners with disabilities are often best served by accommodations that can benefit the entire class. It consists of three different principles: multiple means of engagement, representation, and expression (Table 1).

Table 1. Universal Design for Learning principles

\begin{tabular}{|c|c|c|}
\hline \multicolumn{2}{|c|}{ Universal Design of Learning } \\
\hline $\begin{array}{c}\text { Multiple Means of } \\
\text { Engagement }\end{array}$ & $\begin{array}{c}\text { Multiple Means of } \\
\text { Representation }\end{array}$ & $\begin{array}{c}\text { Multiple Means of } \\
\text { Expression }\end{array}$ \\
$\begin{array}{c}\text { Provide options for } \\
\text { comprehension }\end{array}$ & $\begin{array}{c}\text { Provide options for } \\
\text { comprehension }\end{array}$ & $\begin{array}{c}\text { Provide options } \\
\text { for expression and } \\
\text { communication }\end{array}$ \\
\hline
\end{tabular}

Source: Adapted from the Center for Applied Special Technology (2014).

In considering how these UDL principles apply to assessment in the context of university ESL classes, Wesche's (1983) assessment framework is used to provide structure to the following comments and 
recommendations. In Wesche's framework, any assessment comprises four components: stimulus material, task posed to learners, learners' response, and the scoring criteria.

\section{Stimulus material}

The stimulus material of an assessment is the information that is given to the learners in order to get them to demonstrate their abilities or knowledge. Stimulus material can be linguistic (e.g., written instructions, a text to read) or nonlinguistic (e.g., pictures, diagrams).

The stimulus material component of an assessment is an area in which it is possible that attention to making the material accessible will be beneficial to all learners-not just those with non-apparent disabilities. For example, test instructions can be delivered in multiple formats to ensure that learners understand what they are supposed to do without undue effort. Hearing the teacher read aloud instructions that are also written on the test paper in front of them or projected on a screen are simple but effective ways to improve comprehension. Showing learners what they are meant to do through the provision of example questions is another simple but often neglected way to improve learners' comprehension.

Another general recommendation for improving the comprehensibility of stimulus material is to keep pages or other visual presentations (e.g., a computer screen) uncluttered. An overabundance of words and images in a small space can be distracting and, thus, can impede comprehension. Finally, test makers should consider writing instructions in short sentences ("Read the text. Choose the best answer for each question. Write your answer in the box."), as they are much less cognitively taxing for learners than longer, multi-clause sentences. Modeling the instructions by doing an example question or task together with the class can also be very helpful, to ensure that learners understand what they are meant to do. The instructions are not the place to assess language proficiency!

Use of strategies such as these are in keeping with the UDL principles of engaging and representing through multiple means. 


\section{Task posed to learners}

The task posed to learners is what they are asked to do in order to demonstrate the targeted language abilities. With so many different types of English language classes being offered at colleges and universities, it is difficult to offer any one-size-fits-all solutions in this area. Instead, the authors offer some questions to consider when devising assessment tasks.

1. Is time pressure necessary? It is common to have strict time limits on assessments in higher education ("Pencils down!"), yet allowing extended time is one of the most commonly made accommodations for individuals with disabilities. Consider allowing ample time for all students, perhaps with an extra credit task available for those who finish quickly. While some tasks require students to respond quickly, such as in an oral interview, but not all tasks or elements of language proficiency require time pressure to be validly assessed.

2. In an era of communicative and learner-centered language pedagogy, what role should traditional "pen and paper" tests have? To be sure, there is a place for the traditional vocabulary quiz and similar tasks in higher education classes for ELLs, but authentically assessing communicative ability requires more than multiple choice or fill-in-the-blank questions. Luckily, the types of realistic, contextualized tasks (role plays, interviews, authentic writing tasks, etc.) that are becoming popular with contemporary language testers by their very nature tend to offer multiple means of engagement, representation, and expression. In an assessment involving authentic oral communication, for example, if learners encounter a problem in their conversation, they can try re-stating their point or asking questions.

3. If students would typically have access to resources to accomplish a linguistic task, is it necessary to prohibit the use of those resources during an assessment? For example, if students write papers for homework, they likely have access to dictionaries, their textbooks, and the internet to help them figure out how to express themselves effectively. When might it be appropriate to allow stu- 
dents to use resources like dictionaries, textbooks, and the like in the context of assessment? Of course, there may well be practical issues that require attention (preventing cheating by having students write in class), but do such assessments need to be completely "unplugged" from outside resources?

\section{Learners' response and scoring criteria}

The learners' response is the observable demonstration of learners' abilities or knowledge. How the learners' response is evaluated is the scoring criteria. For example, scoring criteria might manifest as a rubric used to assess learners' writing or the answer key to a traditional test. Like the task posed to the learner, these are elements of assessment for which it is difficult to offer universal solutions. Therefore, we again offer several questions to consider.

1. How important is spelling? It can perhaps be argued that spelling is very important on a vocabulary test. On the other hand, must we consider minor spelling mistakes that do not impede understanding serious enough errors to merit a lower grade on an otherwise well-written essay?

2. How important is grammatical accuracy? Similar to spelling, is native-like grammar always to be required? There is, without a doubt, a place to focus on form and forms in language learning. However, when communication is not impeded, instructors or testers evaluating a learner's performance on a communicative task might consider that successfully completing the task is the best indicator of success, even if the learner's language was not error-free.

3. Finally, is there more than one possible answer or way to do a task successfully? When creating communicative assessments, it is normal to have an idea in mind of what successfully completing the assessment will look like; the tester may have an idea of how many paragraphs and what kinds of information they will contain for a given essay prompt. This is natural and perhaps unavoidable, but we would do well to remain open-minded. Sometimes learners approach tasks in novel ways that work. 
What is being argued here is that, if we take the UDL principle of offering multiple modes of expression, we may need to think carefully about how we assess learners' expression. While the rigors of academia entail upholding certain standards, as part of the learning process, there may be times where flexibility on some of these points ends up being a better choice for promoting learning.

\section{SOME final, general recommendations}

As we have seen, making a few strategic decisions and/or asking oneself probing questions can go a long way towards making assessments accessible and fair for all students, including both those with and without a disability. We offer one final practice to enhance fairness and accessibility: take multiple measures. As Brookhart (2009) points out, "Doctors diagnosing an illness use multiple assessments: the patient's medical history, lab tests, answers to questions about how the patient feels, and so on" (para. 1), so why would educators use only one way (e.g., a final exam) to measure learners' language learning achievement? It is a basic principle of assessment that the more samples of behavior one collects, the more likely the results are to be reliable (Hughes, 2003), so allowing learners more than one opportunity and more than one way to demonstrate their learning is crucial.

Further, at the risk of pointing out the obvious, not all assessment needs to result in a score. Regularly using informal and formative assessment allows the assessment of learners in low-stakes, yet informative ways. Hughes (2003) states that "Assessment is formative when teachers use it to check on progress of their students, to see how far they have mastered what they should have learned, and then use this information to modify their future teaching plans" (p. 5). Take, for instance, the formative assessment technique sometimes called "3-2-1 tickets." In this technique, students are asked, at the end of class, to write three things they understood, two things they wondered about, and one thing they were confused about from the day's lesson. The teacher collects these "tickets" and reviews them to evaluate learning and plan subsequent teaching. This type of assessment can be just as, if not more, informative than a traditional quiz. A plethora of creative formative assessment techniques can be found easily via an internet search. 


\section{Conclusion}

People with disabilities are often considered to be one of the largest minority groups in the world, yet the attention given to diversity seldom extends to learners with disabilities. Learning about this specific ELL population can greatly benefit not only this segment of the population but all learners. Reflecting closely on our practices as English teachers can help us better serve our students.

It should go without saying that accommodations for individual learners are sometimes necessary and important. However, the UDL-inspired assessment strategies and questions offered have one significant advantage over individual accommodations. As Sireci et al. (2005) point out,

if the [individual] accommodation leads to an unfair advantage for the students who get them, for example, if everyone would benefit from the accommodation, then the scores from accommodated exams may be invalidly inflated, which would be unfair to students who do not receive accommodations. (p. 458)

By making assessments more accessible to all students through the use of UDL-inspired strategies, instructors and testers can avoid the difficult task of trying to level the playing field without providing undue or unfair advantage to any individual learners. In other words, UDL is, as the name states, meant to be "universal" and helpful for all learners.

We hope this brief overview and these suggestions will spur educators working with ELLs to reflect on their own assessment practices and to consider how they might be made more accessible to all students without sacrificing the desirable qualities of validity and reliability.

\section{References}

American Psychiatric Association. (2019a). What is ADHD? https://www. psychiatry.org/patients-families/adhd/what-is-adhd

American Psychiatric Association. (2019b). What is autism spectrum disorder? https://www.psychiatry.org/patients-families/autism/what-is-autism-spectrum-disorder 
Brookhart, S. M. (2009). The many meanings of "multiple measures." Educational Leadership, 67(3), 6-12. http://www.ascd.org/publications/ educational-leadership/nov09/vol67/num03/The-Many-Meanings-of-\%C2\%A3Multiple-Measures\%C2\%A3.aspx

Butterworth, B., \& Kovas, Y. (2013). Understanding neurocognitive developmental disorders can improve education for all. Science, 340(6130), 300-305. https://doi.org/10.1126/science.1231022

Center for Applied Special Technology. (2014). Universal design for learning guidelines version 2.1 [graphic organizer]. http://udlguidelines.cast. org/?utm_medium=web\&utm_campaign=none\&utm_source=cast about-udl

Center for Applied Special Technology. (2019). About Universal Design of Learning. http://www.cast.org/our-work/about-udl.html\#.XyHq1vhKjfZ

Hughes, A. (2003). Testing for language teachers. Cambridge University Press. Individuals with Disabilities Education Act, 20 U.S.C. § 1400 of 2004.

Japan Student Services Organization. (2015). 平成26年度（2014年度）障害 のある学生の修学支援に関する実態調査. https://www.jasso.go.jp/gakusei/tokubetsu_shien/chosa_kenkyu/chosa/2014.html

Larson, K., Russ, S. A., Kahn, R. S., \& Halfon, N. (2011). Patterns of comorbidity, functioning, and service use for US children with ADHD, 2007. Pediatrics, 127(3), 462-470. https://doi.org/10.1542/peds.2010-0165

Nakayama W. T., \& Butterworth, B. (1999). A case study of an English-Japanese bilingual with monolingual dyslexia. Cognition, 70, 273-305.

National Center for Education Statistics. (2019). Table 6. MAIN TYPE OF CONDITION: Among undergraduates reporting disabilities, percentage distribution of main type of condition or impairment, by selected demographic and enrollment characteristics: 2011-12. https://nces.ed.gov/Datalab/ TablesLibrary/TableDetails/11798?rst=true

National Center for Learning Disabilities (NCLD). (2014). The state of learning disabilities: Facts, trends and indicators. NCLD.

Sireci, S. G., Scarpati, S. E., \& Li, S. (2005). Test accommodations for students with disabilities: An analysis of the interaction hypothesis. Review of Educational Research, 75(4), 457-490. https://doi. org/10.3102/00346543075004457

Snyder, T. D., Brey, C. d., \& Dillow, S. A. (2019). Digest of education statistics, 2017. https://nces.ed.gov/pubs2018/2018070.pdf 
The International Dyslexia Association. (2019). Definition of dyslexia. https://dyslexiaida.org/definition-of-dyslexia/

Wesche, M. B. (1983). Communicative testing in a second language. The Modern Language Journal, 67(1), 41-55. https://doi.org/10.2307/326692 